\title{
Development Prospect of Agro-Tourism and Positive Effects of Tourism Activities in Rural Regions
}

\author{
Galina Bakhmatova ${ }^{1, *}$ \\ ${ }^{1}$ Federal Rostov Agricultural Research Centre, Institutskaya str., 1, vil. Rassvet, 346735 Rostov \\ district, Russia
}

\begin{abstract}
The spread of technology and innovation in agriculture leads to the emergence of the unemployed. This circumstance leads to the development of non-agricultural activities. Tourism activity in rural areas is a prospective direction. Agro-tourism has an impact on the development of the region and leads to the recovery of traditions, an increase in cultural level and an increase in income. Domestic tourism, including agro-tourism, is in demand in Russia, that is confirmed by statistical data. The wide development of agrotourism makes it possible to study and classify, to identify the main directions of development. The Rostov region has a great tourist potential, both in the health resort and cultural sphere. However, there are difficulties in developing tourism in rural areas, due to the legal insecurity of investors and producers. Despite the difficulties, agrotourism increases the economic potential of the region and has positive effects. Besides, Agrotourism is a real opportunity to restore and maintain the welfare of rural areas, as well as the solution of extremely acute social problems that need to be addressed primarily, in particular, the problems of rural employment, health, education, and leisure. Solving these problems through the development of agro-tourism will promote to the social stability of rural regions.
\end{abstract}

\section{Introduction}

The transition to a new technological structure of domestic agriculture is characterized by an increase in labor productivity, which means that a reduction in employment in the agricultural sector becomes inevitable. Preserving the village as a subsystem of society that performs not only production, but many other important national functions, will require the diversification of the economy by stimulating non-agricultural activities. All developed countries follow this path, and special programs for the development of non-agricultural activities in rural areas are successfully implemented in Europe, the United States, China and others [1-3].

From the perspective of international experience and economic development suggest that agricultural employment will continue to shrink, reduce unemployment only possible due to the non-agricultural sector, to diversify the sources of income in rural areas, contributing to

\footnotetext{
* Corresponding author: bg-fond@mail.ru
} 
the growth of the welfare of rural residents and the preservation of rural settlements. The increase in the level of income attracts qualified personnel to the village, including in agricultural production, and low incomes are now one of the main constraints for the growth of its efficiency.

In recent years, the share of the rural population of the Russian Federation has remained virtually unchanged. In 2018 , it was $25.5 \%$ or 37.7 million people, while the number of people employed in agriculture is steadily declining. The number of agricultural organizations for 10 years has fallen almost by half, from 2.61 million in 2007 to 1.39 million in 2017 , and the number of workers and farm workers, decreased by a quarter - from 470,16 thousand people in 2007 to 377,43 thousand people in 2017. The reasons for such a reduction in the number of people employed in agriculture are both a direct reduction in the number of working farms, and a reduction in the need for unskilled labor as modern agricultural technologies spread, the outflow of the population (especially young people) from rural areas to cities also affects.

The continuing low level of wages makes working in rural areas unattractive for qualified specialists. According to Rosstat, in 2018, the average monthly salary of agricultural workers was 23,301 rubles (compared to 39,167 rubles on average in the economy).

The spread of new digital technologies in agriculture contributes to increasing the requirements for the level of knowledge and skills of personnel - the need for specialists who are ready to work with new equipment, who are versed in precision farming systems, etc. is growing.

The practice of implementing the project "Ensuring employment and increasing the income of the rural population" has shown that the largest number of jobs in rural areas is created in business focused on the local market, and these are usually small business. Much investment has been made into rural tourism in Spain in order to break the monotony of Spanish tourism, which is dominated by beaches and the sun, and also to help farmers gain additional economic income through ways other than agricultural production [4].

Figure 1 shows the structure of small non-agricultural businesses in rural areas in 2019.
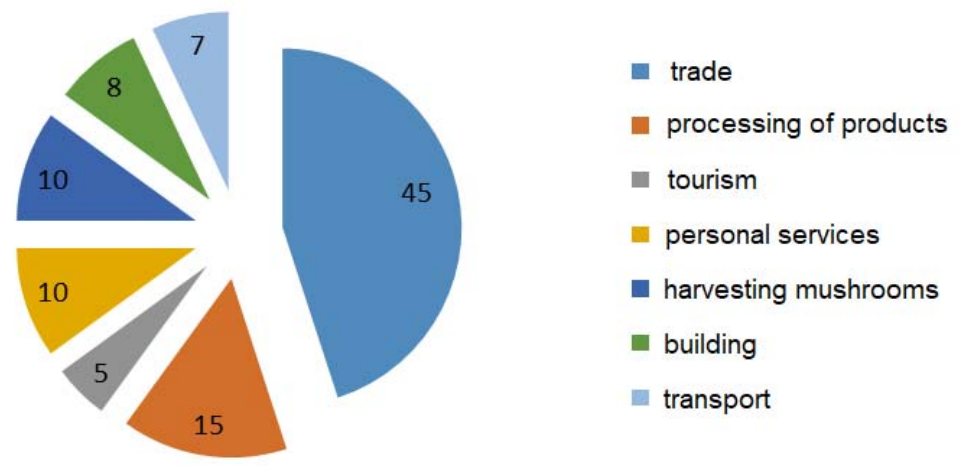

Fig. 1. Structure of agricultural production in rural areas, $\%$

As can be seen from the figure, rural trade is the most important (45\%). Practice has shown that the formation of an extensive network of shops and outbound trade in small villages and remote villages contributes to the development of the market for food and industrial goods, agricultural products; the development of household services; to increase the financial and economic activity of rural entrepreneurs. The non-agricultural sector is mainly represented by activities that serve agriculture and the population. 
Agro-tourism is one of the opportunities for rural development, as it is an alternative to the growing industrialization of society, as well as allows you to create new jobs, and contributes, importantly, to the conservation of nature, as notice many researchers $[5,6]$. Local residents are involved not only in the sphere of tourist services, but also in such industries as the production of folk crafts and souvenirs, acquaintance with national cuisine and costumes, etc. The development will receive work on the improvement of the territory, landscapes, cleaning and waste disposal services, as well as related services in the hospitality sector. Thus, agrotourism will allow to diversify the sectoral composition of rural areas, in addition to agricultural activities, to increase economic stability.

\section{Materials and Methods}

Abstract-logical, statistical-economic, and monographic methods were used in the work, which made it possible to ensure the quality of the study and the validity of the conclusions.

\section{Results}

As of January 2020, there are 4,500 units of rural tourist facilities in our country, with 3,500 being rural guest houses and about 1,000 agro-tourism firms. According to statistics, only $22 \%$ of registered agrotourism objects from all offers in rural areas are registered. The percentage of registered guest accommodation facilities to shadow travel service offers is $1: 3$. Thus, the real number of agrotourism objects is about 20 thousand units.

With an average guest house load of $20 \%$, an average check for accommodation and meals of 2000 rubles / day, and an average stay of 2-3 days, the total annual income of registered guest houses is 2 billion rubles.

Other objects of rural tourism are handicrafts, rural museums, interactive programs are about 10,000 units. Based on the statistics for 2015-2018, agricultural tourism accounts for about $2 \%$ of the total tourism supply in the country.

A significant factor in the Russian agro-tourism market is that it is formed "from below" - in fact, without the participation of central structures. There is no designated political vision for supporting agro-tourism, and, accordingly, there is no national program and financial support (a system of concessional lending, tax and other benefits, etc.). The main active participants in the promotion of agro-tourism are higher educational institutions, the management of museums-reserves and national parks, public organizations, etc.

The absence of a single regulatory framework does not mean a complete lack of work in this area. Regulation of agro-tourism activities is carried out in two directions: state-owned and market-based.

Rural tourism is based on the possibilities of the territories and uses cultural, natural, recreational, etc. the potential of the village, therefore, as a non-agricultural activity is a priority area of diversification, because of agro-tourism concerns health protection, a welfare expressed in the pleasure of life, air and water's quality [7]. According to data for 2018, the volume of commercial products produced by peasant and farm enterprises amounted to 670 billion rubles (approximately $10 \%$ of the total volume of agricultural production). Based on the European experience, the potential of agro-tourism in Russia in the next 10-15 years can be estimated at 50 billion rubles.

Agricultural production in combination with the provision of services, ensuring high economic sustainability of peasant farmers to adverse weather conditions, crop failures, and changes in the market, due to the additional alternative source of income that provides an effective channel for promoting made, natural farm products, and promotes socio-economic development of rural areas. The relevance of tourism for smart specialization is confirmed 
by the dynamics that are currently reconfiguring the sector into a regionally-integrated and knowledge-intensive industry [8].

Figure 2 shows the main factors of agro-tourism development that affect the development of rural areas.

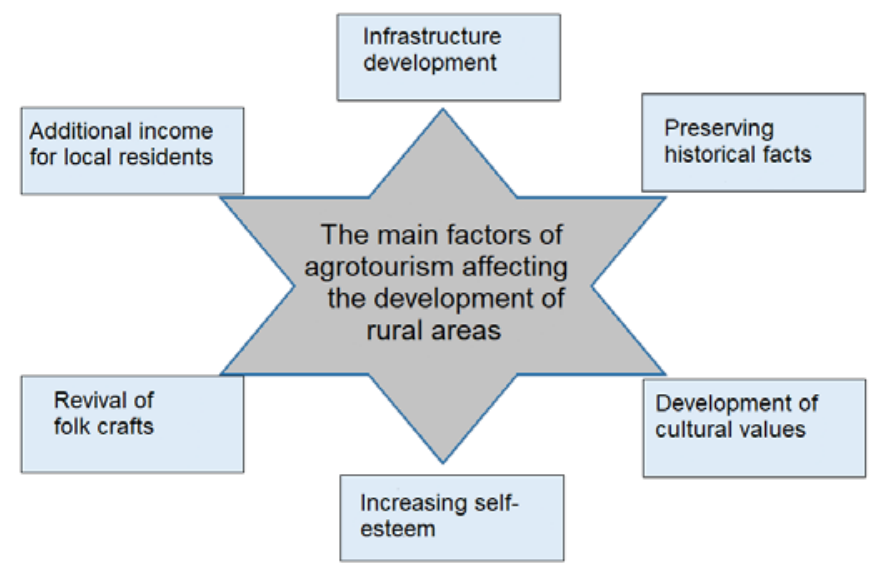

Fig. 2. The main factors of agrotourism affecting the development of rural areas

The experience of state reserves and national parks shows the need for residents to get acquainted with the flora and fauna, which means that familiarity with their region, its culture and customs will be in demand. In the Russian Federation, interest in domestic tourism is increasing, as visits to nature reserves and parks are increasing, and the number of requests to visit centers informing about recreation opportunities is growing (Table 1).

Table 1. Tourist activities in the territory of the state nature reserves and parks

\begin{tabular}{|c|c|c|c|c|c|}
\hline & 2010 & 2015 & 2016 & 2017 & 2018 \\
\hline \multicolumn{6}{|c|}{ State Nature Reserves } \\
\hline Number of museums & 66 & 68 & 67 & 68 & 70 \\
\hline The number of visitors, people & 391224 & 525774 & 522836 & 509660 & 536719 \\
\hline Number of business centers & 108 & 164 & 169 & 171 & 174 \\
\hline The number of visitors, people & 404889 & 503065 & 651943 & 1178222 & 1215339 \\
\hline \multicolumn{6}{|c|}{ National Parks } \\
\hline Number of museums & 48 & 60 & 60 & 59 & 67 \\
\hline The number of visitors, people & 104392 & 170663 & 164946 & 170691 & 237501 \\
\hline Number of business centers & 95 & 143 & 149 & 131 & 128 \\
\hline The number of visitors, people & 176840 & 592693 & 606549 & 544534 & 581900 \\
\hline
\end{tabular}

Moreover, visiting visit centers is almost 2 times higher than the object of entertainment and recreation, which means that informing potential customers should be carried out as widely as possible, since the effectiveness is not yet high.

In 2018, the cost of tourist services totaled 303.7 million rubles, while citizens spent 59.6 million rubles on tourist packages within the country. In connection with the lifting of restrictions, it is planned to increase the tourist flow within the country. In Figure 12, you can estimate the cost and share of tourists.

Traveling around the country allows you to save on the cost of a tour package, so in 2018, $35 \%$ of tourists provided $20 \%$ of the cost of all tour operators services. $57 \%$ of tourists who 
left the Russian Federation paid for $77 \%$ of all services. The effect of domestic tourism is obvious both for the population due to savings on the cost of a tour package, and for the country's economy due to an increase in domestic revenue.

\section{by the cost of tour packages}

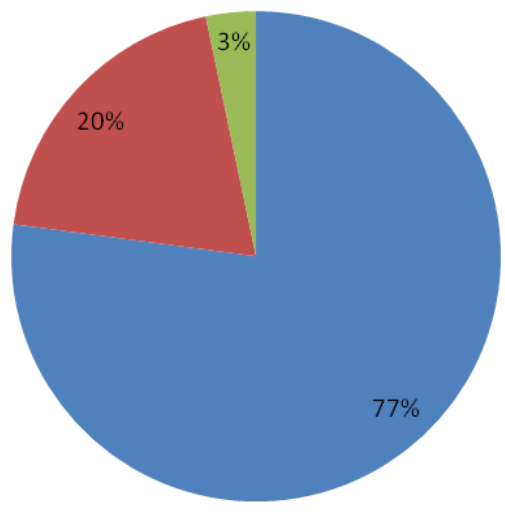

by number of tourists

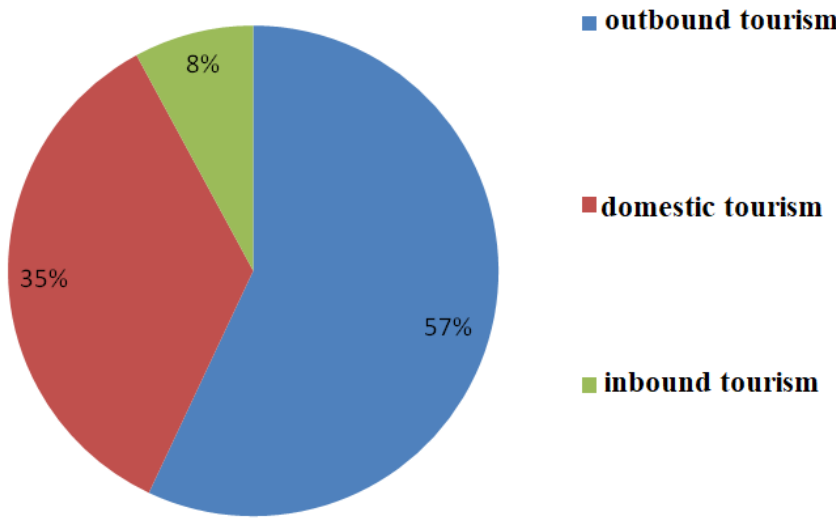

Fig. 3. Division of the number of tourist packages and the number of tourists for 2018 .

Thus, $57 \%$ of tourists who went on vacation abroad are potential consumers of domestic tourist services. The conditions of restrictions in force on the territory of the country allow you to spread information about the possibilities of the regions, as well as attract tourists to a new holiday for them, meet the needs for travel and obtaining new information.

Informing potential tourists about the possibilities of recreation in rural areas is done by including the rural object in numerous and different in form and content Internet resources, where you can find information related to various aspects of rural life.

The leaders in the development of a new type of tourism in Russia are: Vladimir, Vologda, Ivanovo, Novgorod, Arkhangelsk, Leningrad, Penza, Pskov, Samara, Tver, Tula, Yaroslavl regions, the Republics of Karelia and Chuvashia, as well as the Moscow region and the suburbs of St. Petersburg. Rural tourism is divided into several factors (Figure 4). 


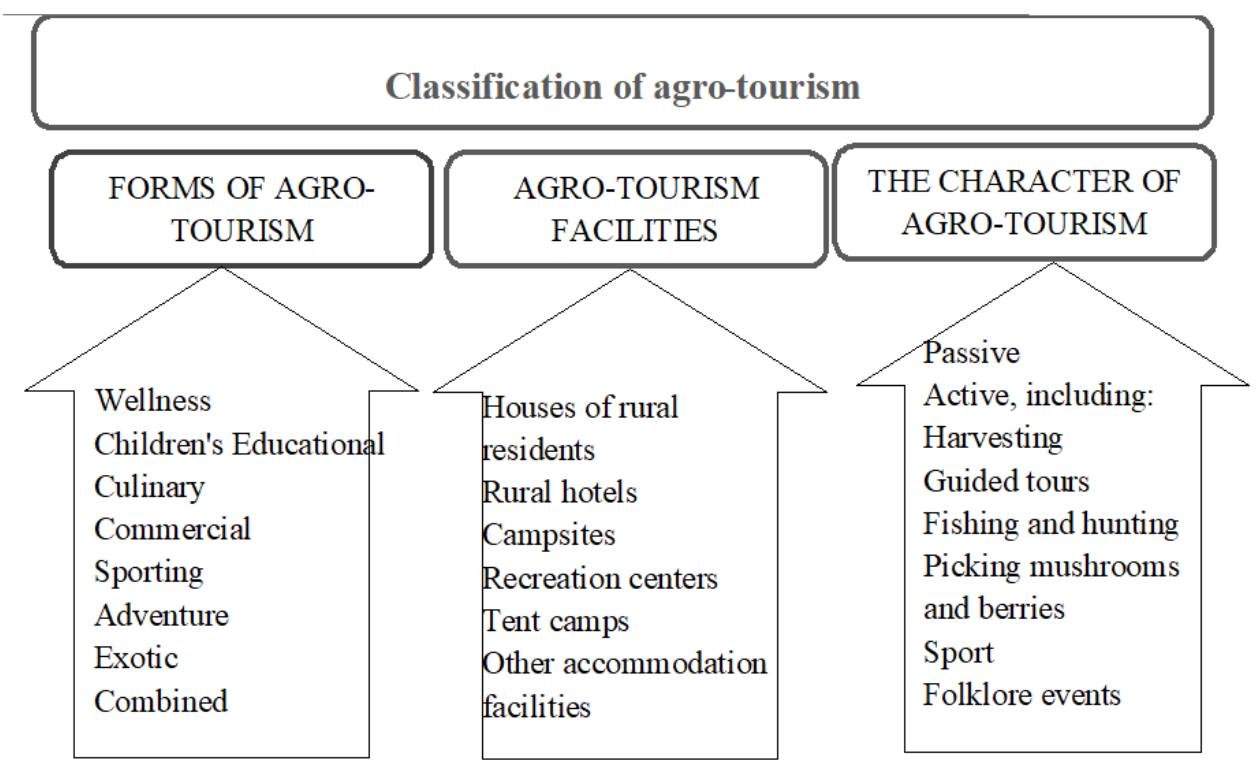

Fig. 4. Classification of agro-tourism

In the practice of rural tourism, tourists are accommodated in converted rural houses and other social facilities, which does not require the construction of expensive hotels.

Possible objects of rural tourism can be:

- ethnographic rural settlements that would reproduce the life of the population in past epochs, taking into account the local color, including the production of food products using ancient technologies (olive-oil tourism [9]);

- hunting and fishing base on which commercial livestock animals and fish are largely the product of human labour (rearing of poultry on farms, improved natural grassland, feeding wild animals, aquaculture artificial or designated portions of natural water bodies, etc.) [10].

Currently, in the countryside was 586,4 thousand of tourist accommodation (table 2).

Table 2. Dynamics of collective accommodation facilities in rural areas

\begin{tabular}{|l|r|r|r|r|r|r|}
\hline & 2014 & 2015 & 2016 & 2017 & 2018 & 2019 \\
\hline $\begin{array}{l}\text { Number of collective } \\
\text { placement facilities }\end{array}$ & 5440 & 5804 & 6039 & 6671 & 6979 & 7235 \\
\hline $\begin{array}{l}\text { Number of seats in } \\
\text { collective accommodation } \\
\text { facilities }\end{array}$ & 397845 & 426265 & 439193 & 509139 & 561661 & 586381 \\
\hline $\begin{array}{l}\text { Number of seats per 1 } \\
\text { collective accommodation } \\
\text { facility }\end{array}$ & 73 & 73 & 73 & 76 & 80 & 81 \\
\hline
\end{tabular}

[GKS]

Compared to 2014, the number of placements increased by 1.5 times. This reflects the growing need for such services in rural areas. And yet, a little more than 7 thousand rural "hotels" for 81 places are not enough for the growing needs, i.e. 4 places of accommodation per 1000 people of the country's population.

Per 1000 people of the rural population, the largest number of placements is in the Southern and Siberian Federal Districts (Table 3). This reflects the ability to attract workers to provide services. 
Table 3. Distribution of the number of placements per 1000 people of the rural population

\begin{tabular}{|c|c|c|c|c|c|}
\hline \multirow[t]{2}{*}{ regions } & \multicolumn{5}{|c|}{$\begin{array}{l}\text { Number of placements per } 1000 \text { people of the rural } \\
\text { population }\end{array}$} \\
\hline & 2014 & 2015 & 2016 & 2017 & 2018 \\
\hline Russian Federation & 10.5 & 11.2 & 11.7 & 13.5 & 15.1 \\
\hline Central Federal District & 11.7 & 11.6 & 11.9 & 11.8 & 11.6 \\
\hline $\begin{array}{l}\text { North-Western Federal } \\
\text { District }\end{array}$ & 14.9 & 14.4 & 14.4 & 14.8 & 18.6 \\
\hline Southern Federal District & 15.3 & 16.7 & 17.1 & 17.9 & 20.3 \\
\hline $\begin{array}{l}\text { North Caucasus Federal } \\
\text { District }\end{array}$ & 1.9 & 2.2 & 2.0 & 2.4 & 3.3 \\
\hline Volga Federal District & 8.9 & 9.8 & 10.2 & 15.5 & 17.8 \\
\hline Ural Federal District & 11.8 & 14.1 & 15.3 & 16.0 & 17.0 \\
\hline Siberian Federal District & 14.2 & 15.9 & 16.5 & 21.0 & 20.3 \\
\hline Far Eastern Federal District & 5.2 & 5.6 & 6.1 & 6.0 & 11.4 \\
\hline
\end{tabular}

During the period under review, all federal districts are increasing their capacity to accommodate tourists, with the exception of the Central Federal District, where the ratio has not changed significantly over a number of years. The North Caucasus Federal District has the least opportunities to provide the hospitality infrastructure with labor resources, while in this region there is an increase in the rural population, the only one in the Russian Federation.

In the structure of the activity of the population traveling in Russia, $80 \%$ are residents of the Central, North-Western, Southern and Volga Federal Districts (Figure 4).

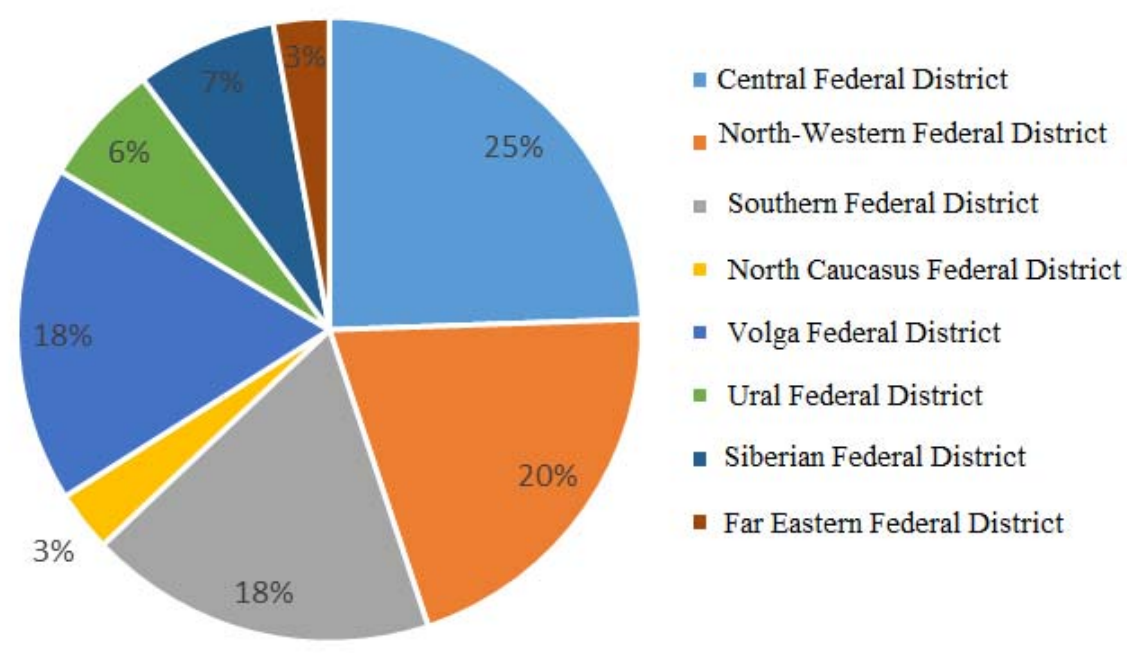

Fig. 4. Division of the number of tourists, in Russia, by federal districts

At the same time, based on the population per 1000, the highest activity of domestic tourism in the North Caucasus Federal District is 93 people per 1000, the Far East-84, the Siberian -70 people. The lowest activity is 20 people per 1000 in the North-Western Federal District. Thus, there are opportunities to increase the influx of tourism focused on travel in Russia.

The main part of trips in Russia are for leisure or medical purposes, business trips make up $2.5 \%$ of the total. In addition to the purpose of leisure activities, which is pursued by $59 \%$ of travelers and health and wellness $-38 \%$, you can distinguish shopping, religious goals and professional training-all together $3 \%$ of the goals of traveling. 


\section{Discussion}

Despite the fact that the Rostov region is one of the largest agricultural regions of the country, where processing of many agricultural crops and livestock products is concentrated, the development of alternative employment in rural areas is very important for it. Rural tourism can become one of the most important resources for the development of rural areas. The Rostov region is mainly a Cossack region.

One of the most striking examples of rural tourism with a focus on ethnographic material is presented in the village of Starocherkasskaya, Rostov region.

On the territory of the Rostov region, a significant part of historical, architectural and cultural monuments (for example, Tanais) is concentrated, customs and rituals, original folklore, and artistic crafts are well preserved, which also increases tourist interest and acts as a significant resource for the development of rural areas.

The village of Starocherkasskaya is visited by delegations not only from all over Russia, but also by foreigners. The guests of the ethnographic center were tourists from England, Germany, Italy, etc.

Thus, we can conclude that the Cossack agrotourism has a great future in the Rostov region, this is indicated by the huge potential of the region, which is the territory, cultural and historical heritage. The development of agrotourism entails the development of the educational sphere. To serve tourists, you need people of such professions as cooks, hairdressers, hotel employees, etc., who need to be trained according to the highest Western level. It gives job for many, especially for woman [11].

To improve the development of rural areas can offer a variety of effective ways, including: - the natural and cultural richness of the Rostov region allows us to develop health, educational, sports and many other types of tourism;

- given the transit situation of our region, it is advantageous to develop auto tourism.

On the official portal of tourism of the Rostov region Visitdon.ru you can find guides to the region, information on districts and cities, places of recreation and entertainment. The interactive map of the attractions of the Rostov region contains information about more than 200 monuments and cultural places.

Tourism activities in rural areas will increase the employment opportunities of the population and stimulate economic activity, gives a synergies effect [12]. However, with the positive impact of rural tourism, this type of activity in rural areas is developing slowly and accounts for $5 \%$ of the structure of non-agricultural production (Figure 1). The main constraints to the active development of tourism are determined by the lack of legislation in this area, the lack of service infrastructure and communication. The necessary condition for rural tourism development is the availability of well-developed infrastructure: means of transport and communication, water, electric power and gas supply, catering, shopping and medical facilities, etc. Although there is a category of tourists (and not so few) who prefer rest and recreation in wilderness, escaping noisy, civilized life [13].

The main thing that hinders the development of tourism activities in rural areas is the lack of legally defined terms "rural tourism" and "agricultural tourism". The absence of a legally defined type of activity makes it difficult to regulate and develop the industry. Also, the difficulties that arise with determining the type of activity give rise to imperfections in tax regulation.

A special place among the factors hindering the development of tourism is the lack of infrastructure. Transport accessibility of villages and villages is far from perfect, but to develop tourism and meet the needs of sophisticated visitors, it is necessary to improve the quality and quantity of roads. Not only is the transport infrastructure outdated and worn out, but the service sector also does not meet modern requirements for the quality of services. 


\section{Conclusions}

Information support for rural tourism activities is weak or not conducted at all. Many potential tourists do not even know about the possibility of visiting memorable or cultural events in transport accessibility. It is important to offer different rural tourism products, thereby improving rural destination management and marketing [14].

To the traditional types of tourism will be added a relatively new, but very promising for Russia way of recreation - agricultural tourism, which has its advantages [15]. Now, there are more than half a million places to accommodate guests in the country's villages and villages. Rural tourism in Russia has a huge potential for further multi-fold growth.

\section{The positive effect of agro-tourism}

Increasing the number of jobs, including for skilled workers

Socio-cultural effect as a result of the activation of local resources, the development of national natural, historical and cultural heritage. the emerg ence of a positive social perspective.

The tourism industry provides a fairly quick return to budgets and initiates the growth of related industries.
The development of the agro -tourism sector in the Russian province is the key to growth-economic, social, cu ltural and spiritual

The realization of the potential of rural regions on the basis of the development of the agro -tourism sector is necessary to overcome the social and spiritual crisis of the Russian province

Sector diversification, reducing dependence on the primary sector

Fig. 4. Efficiency of agro-tourism activities

The development of tourism activities in rural areas makes it possible to increase the economic stability of the region, improve infrastructure security. Tourist attraction is based on the presence of natural or man-made objects that have cultural, aesthetic or other value, which in itself attracts tourists. Thus, by creating favorable conditions for visiting memorable places, the economic activity of the village residents increases, and the inflow of cash receipts from tourist activities is ensured.

However, the positive effects of tourism activities are limited due to the imperfection of the legal framework and the difficulties of determining the type of activity as an object of taxation. Legal insecurity creates fear and distrust of potential investors and entrepreneurs, leaving cultural, social and eco-tourism projects in the framework of episodic activities.

One solution to this problem could be to transfer more powers in the sphere of regulation and the development of rural tourism activities of municipalities, as well as to reduce administrative barriers in terms of mandatory requirements of the regulatory bodies; to introduce in the legislation of the Russian Federation simplified system of registration of rural guest houses and reporting owners selectorates objects.

\section{References}


1. R. Hossein, Z. Bazargani, HasanKiliç, Tourism Management Perspectives 46, 73-72 (2021) doi.org/10.1016/j.jhtm.2020.11.011

2. K. Pitchayadejanant, P. Nakpathom, Kasetsart Journal of Social Sciences 39, 407-413 (2018) doi.org/10.1016/j.kjss.2017.07.004

3. S. Shen, H. Wang, Q. Quan, J. Xu, Tourism Management Perspectives 30, 98-106 (2019) doi.org/10.1016/j.tmp.2019.02.006

4. W. An, S. Alarcón, Journal of Destination Marketing \& Management 19, (2021) doi.org/10.1016/j.jdmm.2020.100549

5. P. Saroyo, G. T. Mulyati, Agriculture and Agricultural Science Procedia 3, 77-77 (2015) doi.org/10.1016/j.aaspro.2015.01.016

6. I. Dinis, O. Simões, C. Cruz, A. Teodoro, Journal of Rural Studies 72, 92-103 (2019) doi.org/10.1016/j.jrurstud.2019.10.002

7. F. D'Alessandro, Agriculture and Agricultural Science Procedia 8, 201-210 (2016) doi.org/10.1016/j.aaspro.2016.02.094

8. P. Del, V. Giuseppina Passiante, Journal of Destination Marketing \& Management 6, 163-165 (2017) doi.org/10.1016/j.jdmm.2016.09.005

9. J. Ignacio Pulido-Fernández, J. Casado-Montilla, I. Carrillo-Hidalgo, Heliyon 5, (2019) doi.org/10.1016/j.heliyon.2019.e02975

10. I. Janowski, S. Gardiner, A. Kwek, Tourism Management Perspectives 37, (2021) doi.org/10.1016/j.tmp.2020.100776

11. I. Gavrilă-Paven, Procedia - Social and Behavioral Sciences 188, 111-115 (2015) doi.org/10.1016/j.sbspro.2015.03.345

12. F. G. Santeramo, A. Seccia, G. Nardone, Wine Economics and Policy 6, 71-74 (2017) doi.org/10.1016/j.wep.2016.11.004

13. O. Paresishvili, L. Kvaratskhelia, V. Mirzaeva, Annals of Agrarian Science 15, 344-348 (2017) doi.org/10.1016/j.aasci.2017.07.008

14. C. Eusébio, M. J. Carneiro, E. Kastenholz, E. Figueiredo, D. Soares da Silva, Journal of Hospitality and Tourism Management 31, 197-210 (2017) doi.org/10.1016/j.jhtm.2016.12.006

15. G.-P. Ionela, B. M. Constantin, L.-D. Dogaru, Procedia Economics and Finance 32, 1050-1059 (2015) doi.org/10.1016/S2212-5671(15)01567-1 